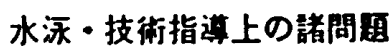

上智大学吉 四 勝 平

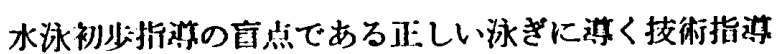
仆茨の碓士乚のための闍题点の究明.

\section{1. 基本の泳き}

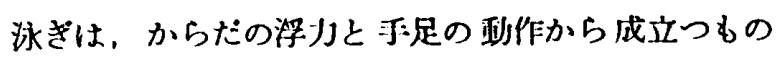

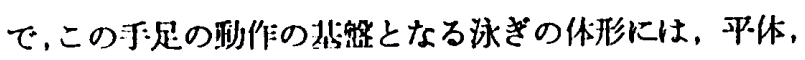

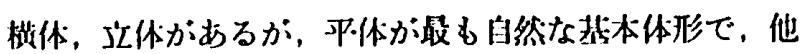
は特列体形である。

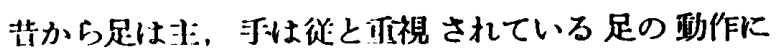

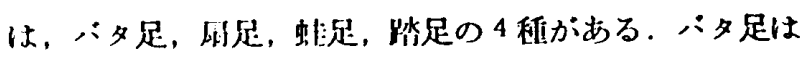

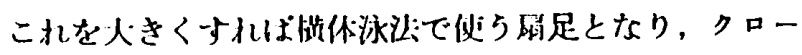

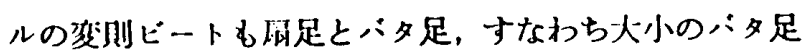
が約み命わされたものであり，特殊なドルフイン・キツク

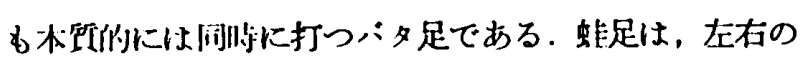
足の褧を伐つて间川少に踏及挾むるので，こ机を交互に踏

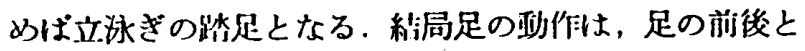

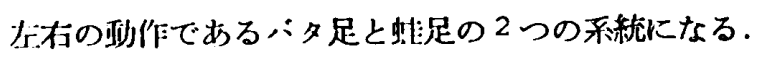

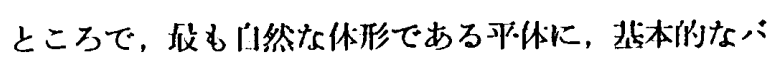

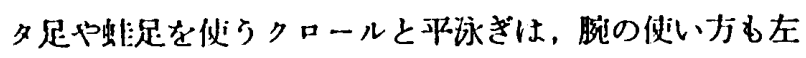

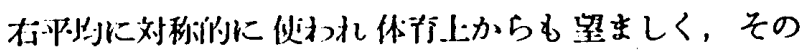
」之，少し手足の詶子やや体形に变化を加光れしば，他の目的 にもコ浱に役立つ度も想想的な其本泳治である。

\section{2. 正しい河き}

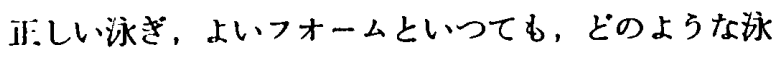
ぎが汇しい泳ぎかあきらかでないか，次のような泳ぎを 口細にしたい。

\section{(1)やわらかい㽖作の泳ぎ}

陸上です，なれないとぎこちない䣦作になるが，泳ぎ

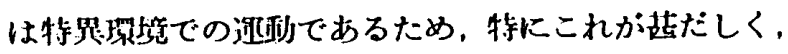

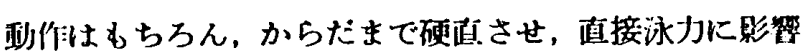
ナるだけでなく，技術畾待の大きな障豐となる。

このこわばりをとりのぞくためには，精神面の原因を

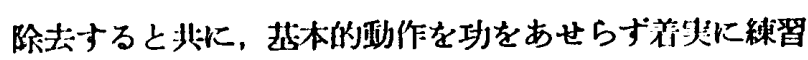

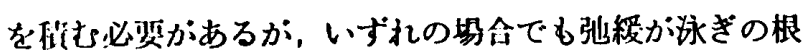
本であり，粎署の焦点である。

(2) 水身一致の泳き

泳ぎ览林休形である平浮きによき手足の副作が加わ
つてはじめてよい泳ぎが生れるむので,そのためには頭 や胸部を沈めて体を水に任せることである．これにより 自然に体か浮揚し，手足はもつばら推進のために使われ ろので負担が轻く，自由に力を脱くこともできらくに稆 習もできる。しかす，この体形は抵抗が少く，その上推 進によつて浮力る生れる取も合理的な体形でるある。

(3) 伸びのある泳ぎ

泳ぎは，疲机ても休むことができない，しかも强い運 䡃とされているか，これをるつとらくに永桡きさせるた めには，ひとつひとつの泳ぎ間に休みを入れ，閌合い を取つて泳ぐことである。これが泳ぎ独特の伂びであつ て，水に乗り，水の抵抗を有効に受けるためにも大切な むのである。

(4) 合理的な動作の泳ぎ

泳ぎは，水を御する特殊技能であるが，案外めちやく ちやに手足を動かし，りきみ過き，却つて日的に反する 動作をで加わえているものが多い，犬搔きの押し手，ク ロ一ルのバ足など景気よく水上まで出すが，有効な動 作は水中であり，平泳ぎ手足は，平面でなく立体的動 作に，クロールの手は円でなく杵円運動にと，より命理 们䣦作で泳ぐべきである。

\section{3. 呼 吸 法}

泳ざでの呼吸は，水で制約を受けるばかりではなく，

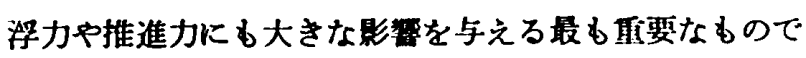
ある、特に初步においては，水伍れのための息止めはか りではなく，恐怖心を取りのぞくらえからも大切であ ク，下手な呼玔は我腔に痛及を起すたけではなく，不用 意に舅から吸いこんた水か取管から中耳にはいり中耳炎 を起すこともあり，泳ぎ第】歩から注意深く指举せね2 ばならない.

呼気（水中で秘から静かに吐き出し読计），吸気（水 上に顔を出し口を明ける），昍くことに可点をおき，口 を開ければ空気が自然に肺にはいつてくるよう練習を称 ts.

\section{宜つまみ法（陸上楝習）}

片手の母指と人さし指を小留の両側におき，十分息を 自から出しきつたら楀をつまみ口を開ける、 